\title{
Do the Personality Traits of Teacher Candidates Predict the Perception of Self-Efficacy and Alienation from School?
}

\author{
Tamer SARI * \\ School of Foreign Languages, Department of Foreign Languages, Pamukkale University, \\ Denizli, Turkey \\ ORCID: 0000-0003-3752-9277
}

Servet ATIK

Faculty of Education, Department of Educational Sciences, Inonu University,Malatya, Turkey ORCID: 0000-0003-2841-6182

\author{
Osman Tayyar Çelik \\ Faculty of Health Sciences, Department of Child Development, Inonu University, \\ Malatya,Turkey
}

ORCID: 0000-0003-3951-7261

Article history

Received:

06.03.2021

Received in revised form: 30.04.2021

Accepted:

17.05.2021

Key words:

Teacher candidates;

Teacher training;

Personality traits;

Self-efficacy;

Alienation from school
Certain personality traits have been associated with effective teacher behavior for many years. In addition, in recent years, there has been a growing interest in the discussion of the evaluation of personality traits as criteria in the selection of teacher candidates. However, researchbased evidence was needed on how personality traits affect teacher candidates. This study examined the relationship between teacher candidates' personality traits and their self-efficacy perceptions and their alienation from school. The research was designed in the correlational research design. The participants of the study consisted of 516 teacher candidates studying at two universities, one is in the West and the other is in the East of Turkey. Descriptive statistics and multiple linear regression analysis were used to analyze the data. The results of the research showed that the personality traits of the teacher candidates significantly predicted their self-efficacy perceptions and their alienation from the school when gender and department selection decision were controlled. Extraversion, openness, conscientiousness, and agreeableness positively predicted teachers' self-efficacy, whereas neuroticism predicted negatively. Unexpectedly, extraversion positively predicted the normlessness dimension of alienation from school. The results were discussed in the context of the evaluation of personality traits in the selection of teacher candidates and the teacher training process.

\footnotetext{
* Correspondency: tamersari@gmail.com
} 


\section{Introduction}

Teacher training programs are a critical period in the acquisition of effective teacher skills. The selection of people suitable for the profession, the experiences in the education process are important determinants of teacher effectiveness in the following periods. With the developments in personality measurements in recent years, discussions on whether personality traits should also be considered as a criterion in the selection of teachers and therefore teacher candidates have been on the agenda again (Biermann, Karbach, Spinath \& Brünken, 2015; Corcoran \& O'Flaherty, 2016; Kim, Dar-Nimrod \& MacCann, 2018). However, although teacher competencies are an indispensable feature in the context of education, when the subject is evaluated in terms of the definition of a good teacher, very few answers were related to competence (Vorkapić, 2015). In studies on effective teacher characteristics (Özabac1 \& Acat, 2005; Ubuz \& Sar1, 2009) although personality traits stand out, there was a consensus among researchers that teaching was a profession that requires personality traits such as conscientiousness, openness to change, and being humane (K1z1ltepe, 2002; Özkan \& Arslantaş, 2013).

Although the concept of personality is used frequently in daily conversations, it has indeed been defined in many different ways (Erdoğan, 2007). Some of the definitions of personality are "consistent behaviour patterns and internal processes originating from the individuals themselves" (Burger, 2006), "the whole formed by the innate or acquired traits of individuals" (Güney, 2014), "the integrity of the individual, consistent and structured characteristics that distinguish individuals from others, (İnanç \& Yerlikaya, 2011)," a continuous and structured collection of mental characteristics and mechanisms that affect people's communication with their physical, psychological and social environments, as well as various characteristics, beliefs and mental states that distinguish one person from another" (Noreen, Ali, \& Munawar, 2019, p.92). It can be argued that definitions of personality generally emphasize consistency in behaviour and holistic characteristics that differentiate individuals from others.

A consensus has been reached on the Big Five Factor Personality Model as one of the most important paradigms in defining personality structure (Corcoran \& O'Flaherty, 2018; Evans, Martin, \& Ivcevic, 2018; Göncz, 2017). Costa and McCrae's (1992, 2006) studies conceptualized personality traits under five factors. These five factors, which were initially only the classification of personality traits, have turned into a personality theory over time (İnanç \& Yerlikaya, 2011). The dominant view in psychological personality theories also supports the big five-factor personality model theory (Rimm-Kaufman \& Hamra, 2010). These five factors are neuroticism, extraversion, openness, agreeableness, and conscientiousness.

As in many countries such as South Korea, Japan (Mete, 2013), central exam scores are taken as criteria in the selection of teacher candidates in Turkey. Ignoring personality traits and focusing only on academic performance exhibited in national high stakes exams in the selection of teacher candidates was a criticized approach (Corcoran \& O'Flaherty, 2016; Özer \& Alkan, 2017). In the teacher candidate selection models proposed by the researchers, personality traits were commonly included as evaluation criteria (Canbulat, K. Canbulat, 2015; Özer \& Alkan, 2017; Polat \& Arabac1, 2012). Nonetheless, it was suggested that evidence-based studies were needed for the relationship between personality traits and different variables (Biermann et al., 2015; Kim et al., 2018). In the studies conducted, it was concluded that there were significant relationships between teacher candidates' personality traits and academic performance (Smidt, 2015), attitudes towards the teaching profession (Üstüner, 2017), communication skills (Dere, 2018) and professional anxieties (Çelik \& Şengül, 2017). Another variable that might be related to personality trait was alienation from school. In this context, one of the main questions guiding 
this study was whether personality traits could predict teacher candidates' alienation from school.

As a matter of fact, alienation has become an important problem in the educational context in recent years. According to Mann, (2001) in order to reduce the alienation of students, it was necessary to support teachers' empathy and openness characteristics, to provide a psychologically safe environment for students, to help teachers? participate in the decision making process and to pay attention to the sources of alienation in the educational environment (as cited in Osin, 2017). The emphasis has hitherto been mostly on environmental factors, and thusly individual factors such as personality traits were often ignored in alienation. Emotions such as meaninglessness and powerlessness that an individual experiences arise mostly due to internal regulations. Personality traits were considered to be directly related to alienation due to including consistent behaviour and attitudes.

Another psychological variable that may be affected by the personality traits of teacher candidates is self-efficacy perception. According to Bandura (1997), one of the sources of selfefficacy was physiological and emotional states. In this context, it was stated that certain personality traits could cause positive and negative emotional experiences and accordingly, they would serve as a source of information (Jamil, Downer, \& Robert, 2012; Perera, Granziera, $\&$ McIlveen, 2018). It was clear that building strong efficacy beliefs was an important part of teachers' development, and an important process for building competence was teacher training programs (DeMauro \& Jennings, 2016). Since beliefs such as self-efficacy may affect teacher candidates' future professional practices and teaching competencies, revealing the relationship between personality traits and self-efficacy may contribute to the structuring of teacher preparation programs.

\section{Purpose and significance}

While evaluating the effectiveness of education, teacher quality was one of the most discussed topics. The selection of qualified and professional candidates, the quality of preservice programs, and continuous professional development were considered as ways to increase teacher qualifications. It was suggested that personality traits might be used as a selection criterion in the selection of teacher candidates, but psychological factors such as personality traits could affect teacher candidates' professional development, academic achievement and social relations during the education program given in faculties (Mahoney \& Quick, 2000). In this context, it might be considered that studies on how personality traits affect teacher candidates in higher education process were necessary. Current research was expected to provide clues about whether personality traits would be an important criterion for the selection of teacher candidates, in the development of teaching and intervention programs. Based on this need, the relationship among teacher candidates' personality traits, self-efficacy, and alienation from school was discussed in the study. In this context, the main questions of the research are structured as follows.

(1) Do teacher candidates' personality traits significantly predict their self-efficacy perceptions?

(2) Do teacher candidates' personality traits significantly predict their alienation from school? 


\section{Methodology}

A correlational research design was used to examine the relationship between teacher candidates' personality traits, self-efficacy perceptions and alienation from school. Correlational research is divided into two as explanatory and predictive methods (Zayim, 2018). The predictive method was used in this study. In the predictive method, the independent variable is called the predictor variable, while the dependent variable is called the predicted variable (Fraenkel, Wallen, \& Hyun, 2012). In the study, the personality traits of teacher candidates were the predictor variables, teacher candidates' self-efficacy perceptions and their alienation from school were predicted variables.

\section{Population and sampling}

The population of the study was constituted by the students of the faculty of education in two universities, one is in the West and the other is in the East of Turkey, the sampling consisted of 516 teacher candidates who were determined by using purposive and simple random sampling method. Within the scope of purposive sampling, students in the first year of the faculty were not included in the sample, considering that they could not have sufficient school experience, and hence the second, third and fourth year students were included in the sample. Within the scope of simple random sampling, volunteer teacher candidates were invited to the study to fill in the data collection tools. Data collection tools were applied face to face by the researchers in the 2019-2020 academic year fall term. Before applying the scale forms, the teacher candidates were informed about the study and the volunteers were asked to fill the forms. Demographic characteristics of the participants are $75 \%$ female $(\mathrm{n}=387)$ and $25 \%(\mathrm{n}=$ 129) male in terms of gender. $12.4 \%(\mathrm{n}=64)$ of them are second year students in terms of educational degrees, 35.5\% $(\mathrm{n}=183)$ are third year students, $52.1 \%(\mathrm{n}=269)$ are fourth year students, in terms of department preference $82.6 \%(n=426)$ declared they preferred their department voluntarily, but $17.4 \%(n=90)$ shared they chose the department due to social pressures.

\section{Measures}

Demographic Information Form, Big Five Factor Personality Traits Scale, Student Alienation Scale and Teacher Self-Efficacy Scale were used in the study to collect data.

Big Five factor personality traits scale. "Big Five Factor Personality Traits Scale" developed by Costa and McCrae (1992) and its short form by Benet-Martinez and John (1998) was used to determine the personality traits of teacher candidates. The scale consists of five subdimensions and 44 items. These dimensions are neuroticism, extroversion, openness, agreeableness, and conscientiousness. The scale was adapted into Turkish by Sümer, Lajunen and Özkan (2005) in the sample of university students. In the adaptation study, it was concluded that the Crombach Alpha reliability coefficients of the sub-dimensions of the scale varied between .64 and .77. In this study, the Cronbach Alpha coefficient for the sub-dimensions of the scale was calculated as neuroticism (.82), extraversion (.80), openness (.80), agreeableness (.76), and conscientiousness (.72).

Teacher self-efficacy scale. Teacher candidates' self-efficacy perceptions were measured with the "Teacher Self-Efficacy Scale" developed by Tschannen-Moran and Woolfolk Hoy (2001) and adapted into Turkish by Çapa, Çakıroğlu and Sarıkaya (2005) for teacher candidates. The scale consists of three sub-dimensions and 24 items. These dimensions are teaching strategies self-efficacy, classroom management self-efficacy, and student engagement self-efficacy. In the adaptation study conducted by Çapa, Çakıroğlu and Sarıkaya (2005), confirmatory factor 
analysis and Rash analysis were used within the scope of the validity studies of the scale. As a result of the analysis, it was determined that the scale structure and all items of the scale had acceptable fit values. Cronbach Alpha internal consistency coefficient was calculated within the scope of reliability. As a result of the analysis, the Cronbach Alpha internal consistency coefficients of the scale were calculated for the student engagement sub-dimension (.82), for the classroom management sub-dimension (.84), for the teaching strategies sub-dimension (.86), and for the overall scale (.93). In this study, the Cronbach Alpha coefficient for the subdimensions of the scale was calculated as teaching strategies self-efficacy (.85), classroom management self-efficacy (.81), and student participation self-efficacy (.83). Self-efficacy variable was analysed as total score.

Student alienation scale. The alienation of teacher candidates was measured with the "Student Alienation Scale" developed by Çağlar (2012). The scale was developed to measure the alienation of university students from school. The scale consists of four sub-dimensions and a total of 20 items. These dimensions are powerlessness, meaninglessness, normlessness and isolation. As a result of the confirmatory factor analysis applied by Çağlar (2012), it was determined that $\mathrm{x} 2$ / sd ratio was 1.99 NNFI and CFI was .95, GFI was .91, RMSEA was .05, AGFI was .89, and therefore the scale structure was confirmed. Within the scope of reliability, Cronbach's Alpha reliability coefficients were calculated as .79 for powerlessness, .75 for normlessness, 76 for isolation, 76 for meaninglessness, and .86 for the overall scale. In this study, the Cronbach Alpha coefficient for the sub-dimensions of the scale was calculated as powerlessness (.81), meaninglessness (.72), normlessness (.75), isolation (.72).

\section{Data analysis}

Data analysis was carried out in two stages. In the first stage, whether the data were suitable for multivariate analysis was examined. In this context, the skewness and kurtosis coefficients and multiple connectivity of the data were examined. The results obtained were presented in Table 1.

Table 1. Skewness, kurtosis, tolerance and VIF values for the data

\begin{tabular}{lllll}
\hline Variables & Skewness & Kurtosis & Tolerance & VIF \\
\hline Extroversion & .403 & .650 & .808 & 1.238 \\
Agreeableness & -.301 & -.295 & .758 & 1.319 \\
Conscientiousness & -.08 & -.058 & .744 & 1.345 \\
Neuroticism & -.97 & .565 & .867 & 1.154 \\
Openness & -.179 & -.464 & .820 & 1.220 \\
Gender & & & .963 & 1.039 \\
Department selection decision & & & .984 & 1.016 \\
Meaninglessness & .364 & -.358 & & \\
Powerlessness & .293 & -.185 & & \\
Normlessness & .253 & -.281 & & \\
Isolation & .385 & -053 & & \\
Self-efficacy & -.292 & .569 & & \\
\hline
\end{tabular}


When Table 1 was examined, it was determined that skewness values varied between (-.301, $.403)$ and kurtosis values between $(-.464, .65)$. It can be said that this distribution is within the range of values accepted for normality (Karagöz, 2016). Whether there was a multicollinearity problem among the variables to be included in the analysis together was examined by looking at the correlation analysis, VIF and Tolerance values. It was observed that there were no strong relationships between the variables such as .80 and above (see table 2), VIF values were less than .10 and tolerance values were higher than .10. Therefore, it can be assumed that the data were ideal for multivariate analysis (Çokluk, 2010). In the second step, descriptive statistics and multiple linear regression analysis were applied. In multiple linear regression analyses, personality traits were included as independent variables, alienation sub-dimensions and selfefficacy as dependent variables. There are studies reporting the relationship between gender and department selection decision with self-efficacy perception and alienation (Author, 2020; Polat, Dikmen, \& Asul, 2015; Yaman, Koray, \& Altunçekiç, 2004; Yeşilyurt, 2013). In this context, gender and department selection decision were added as control variables while performing regression analysis.

\section{Results}

Descriptive statistics on teacher candidates' perceptions of alienation from school, personality traits and self-efficacy are presented in Table 2.

Table 2. Averages, standard deviations and correlations to variables of school alienation, personality traits and self-efficacy

\begin{tabular}{lllllllllllll}
\hline Variables & 1 & 2 & 3 & 4 & 5 & 6 & 7 & 8 & 9 & 10 & $\mathrm{X}$ & $\mathrm{Sd}$ \\
\hline 1. Powerlessness & - & & & & & & & & & & 2.61 & .82 \\
2. Normlessness & $.33^{* *}$ & - & & & & & & & & & 2.79 & .88 \\
3. Isolation & $.32^{* *}$ & $.32^{* *}$ & - & & & & & & & & 2.62 & .86 \\
4. Meaninglessness & $.41^{* *}$ & $.58^{* *}$ & $.30^{* *}$ & - & & & & & & & 2.81 & .93 \\
5. Extroversion & $-.12^{* *}$ & .03 & $-.17^{* *}$ & -.03 & - & & & & & & 3.55 & .75 \\
6. Agreeableness & $-.18^{* *}$ & $-.19^{* *}$ & $-.20^{* *}$ & $-.21^{* *}$ & $.24^{* *}$ & - & & & & & 3.87 & .58 \\
7. Conscientiousness & $-.23^{* *}$ & $-.23^{* *}$ & $-.15^{* *}$ & $-.28^{* *}$ & $.21^{* *}$ & $.44^{* *}$ & - & & & & 3.56 & .60 \\
8. Neuroticism & .09 & $.14^{* *}$ & $.28^{* *}$ & $.13^{* *}$ & $-.30^{* *}$ & $-.15^{* *}$ & $-.20^{* *}$ & - & & & 3.08 & .64 \\
9. Openness & $-.16^{* *}$ & -.03 & -.07 & $-.10^{*}$ & $.30^{* *}$ & $.29^{* *}$ & $.31^{* *}$ & $-.09^{*}$ & - & & 3.45 & .44 \\
10. Self-efficacy & $-.22^{* *}$ & -.01 & -.10 & -.06 & $.35^{* *}$ & $.34^{* *}$ & $.39^{* *}$ & $-.23^{* *}$ & $.37^{* *}$ & - & 3.73 & .51 \\
\hline **p<.01, *p $<.05$ & & & & & & & & & & & &
\end{tabular}

Teacher candidates have a higher average $(X=2.81)$ in the meaninglessness dimension of alienation from school compared to other dimensions, while they have the lowest average (X= 2.61) in the dimension of powerlessness. However, it can be seen that there is no comparable distinct difference in the averages. While the teacher candidates have a significantly lower average $(X=3.08)$ in neuroticism personality trait than other dimensions, they were in the highest average $(X=3.87)$ in the agreeableness dimension. Teachers' self-efficacy perceptions of the candidates can be indicated to be over the average level. Considering the correlations between variables, while extroverted personality trait is negatively correlated between powerlessness $(\mathrm{r}=-.12)$ and isolation $(\mathrm{r}=-.17)$, it is positively associated with self-efficacy $(\mathrm{r}=$ .35). Agreeableness and conscientiousness personality traits were negatively correlated with 
each of the alienation sub-dimensions, but both personality traits were positively associated with self-efficacy. Neuroticism has positive relationship with normlessness $(r=.14)$, isolation $(\mathrm{r}=.28)$, and meaninglessness $(\mathrm{r}=.13)$, but a negative relationship with self-efficacy $(\mathrm{r}=-.23)$. It has been determined that the dimension of openness has a negative relationship with the dimensions of powerlessness $(r=-.16)$ and meaninglessness $(r=-.10)$, but a positive relationship with self-efficacy $(r=.37)$. Finally, when the relationships between alienation sub-dimensions and self-efficacy are examined, only powerlessness showed a significant negative relationship $(r=-.22)$.

Multiple linear regression analysis was conducted to determine whether personality traits predict teacher candidates' self-efficacy perceptions. Gender and department selection decision were added to the model as control variables. The results obtained are presented in Table 3.

Table 3. Multiple linear regression analysis results on the prediction of personality traits on self-efficacy

\begin{tabular}{llll}
\hline Variables & $\mathrm{B}$ & $\mathrm{Sd}$ & $\beta$ \\
\hline Control variables & & & $.079^{*}$ \\
Gender & .092 & .044 & .054 \\
Department selection decision & .009 & .006 & \\
$\Delta \boldsymbol{R}^{2}$ & $\mathbf{. 0 1 4}$ & & \\
Personality traits & & & $.183^{* * *}$ \\
Extroversion & .123 & .028 & $.129^{* *}$ \\
Agreeableness & .113 & .037 & $.216^{* * *}$ \\
Conscientiousness & .182 & .036 & $-.098^{*}$ \\
Neuroticism & -.078 & .031 & $.208^{* * *}$ \\
Openness & .239 & .047 & \\
$\Delta \boldsymbol{R}^{2}$ & $\mathbf{. 2 9 6}$ & & \\
Model $\boldsymbol{R}^{2}$ & $\mathbf{. 3 0}$ & & \\
Model F & $\mathrm{F}(5.510)=42.974^{* * *}$ & \\
\hline
\end{tabular}

${ }^{*} \mathrm{p}<.05, * * \mathrm{p}<.01, * * * \mathrm{p}<.001$

The model in which the control variables were evaluated together explained approximately $1 \%$ of the variance in the self-efficacy perceptions of teacher candidates. Although this ratio is quite low, the contribution of gender to the model $(=.079, \mathrm{p}<.05)$ was significant, while the contribution of the decision to select the department to the model $(=.054, \mathrm{p}>.05)$ was not significant. Since female students are taken as reference values in gender variable, it can be said that male students had higher self-efficacy perceptions. The personality traits added to the model after controlling the department selection decision and gender variables explained approximately $30 \%$ of the variance in self-efficacy perception. While all personality trait dimensions contributed significantly to the model, the most important positive predictor was conscientiousness, while the only negative predictor was neuroticism. As a result, it can be reported that teacher candidates' personality traits could predict a significant proportion of the variance in their self-efficacy perceptions. While agreeableness, openness, extraversion and conscientiousness correspond to high self-efficacy perception, neuroticism accompanies low 
self-efficacy perception in teacher candidates.

Multiple linear regression analysis was conducted to determine whether personality traits predicted teacher candidates' alienation from school. Gender and department selection decision were also added to the model as control variables. Results were presented in Table 4.

Table 4. Multiple linear regression analysis results on the prediction of personality traits on alienation from school

\begin{tabular}{|c|c|c|c|c|c|c|c|c|c|c|c|c|}
\hline \multirow{2}{*}{ Variables } & \multicolumn{3}{|c|}{ Meaninglessness } & \multicolumn{3}{|c|}{ Powerlessness } & \multicolumn{3}{|c|}{ Normlessness } & \multicolumn{3}{|c|}{ Isolation } \\
\hline & B & SE & $\beta$ & $\mathrm{B}$ & $\mathrm{SE}$ & $\beta$ & B & SE & $\beta$ & B & $\mathrm{SE}$ & $\beta$ \\
\hline \multicolumn{13}{|l|}{ Control variables } \\
\hline Gender & .481 & .093 & $.223^{* * *}$ & .146 & .083 & .077 & .254 & .089 & $.125^{* *}$ & -.090 & .089 & -.045 \\
\hline $\begin{array}{l}\text { Department selection } \\
\text { decision }\end{array}$ & -.006 & .014 & -.019 & .015 & .012 & .055 & .013 & .013 & .042 & .013 & .013 & .042 \\
\hline$\Delta R^{2}$ & \multicolumn{3}{|c|}{.05} & \multicolumn{3}{|c|}{.009} & \multicolumn{3}{|c|}{.017} & \multicolumn{3}{|c|}{.002} \\
\hline \multicolumn{13}{|l|}{ Personality traits } \\
\hline Extroversion & .104 & .057 & .083 & -.051 & .052 & -.046 & .151 & .055 & $.127 * *$ & -.077 & .054 & -.067 \\
\hline Agreeableness & -.135 & .077 & -.083 & -.103 & .070 & -.072 & -.195 & .074 & $-.127 * *$ & -.224 & .073 & $-.148 * *$ \\
\hline Conscientiousness & -.342 & .074 & $-.219 * * *$ & -.234 & .068 & $-.170 * *$ & -.274 & .072 & $-.186^{* * * *}$ & -.069 & .071 & -.047 \\
\hline Neuroticism & .182 & .064 & $.125 * *$ & .039 & .059 & .031 & .205 & .062 & $.148^{* *}$ & .309 & .061 & $.227 * * *$ \\
\hline Openness & -.054 & .096 & -.025 & -.131 & .088 & -.070 & .089 & .093 & .044 & .056 & .091 & .028 \\
\hline$\Delta R^{2}$ & \multicolumn{3}{|c|}{.093} & \multicolumn{3}{|c|}{.073} & \multicolumn{3}{|c|}{.092} & \multicolumn{3}{|c|}{.111} \\
\hline Model $R^{2}$ & \multicolumn{3}{|c|}{.143} & \multicolumn{3}{|c|}{.082} & \multicolumn{3}{|c|}{.109} & \multicolumn{3}{|c|}{.113} \\
\hline Model F & \multicolumn{3}{|c|}{$F(2.513)=12.153 * * *$} & \multicolumn{3}{|c|}{$F(2.513)=6.466^{* * *}$} & \multicolumn{3}{|c|}{$F(2.513)=8.876^{* * *}$} & \multicolumn{3}{|c|}{$F(2.513)=9.206^{* * *}$} \\
\hline
\end{tabular}

$* \mathrm{p}<.05, * * \mathrm{p}<.01, * * * \mathrm{p}<.001$

Among the control variables in the models, only gender made significant contribution to the explanation of meaninglessness $(\beta=.223, \mathrm{p}<.001)$ and normlessness $(\beta=.125, \mathrm{p}<.001)$ subdimensions. Since female students were taken as a reference for gender, it can be expressed that male students might experience higher sense of meaninglessness and normlessness. The model created for the meaninglessness dimension explained approximately $14 \%$ of the variance. Personality traits that made a significant contribution to the model were conscientiousness $(\beta=$ $-.219, \mathrm{p}<.001)$ and neuroticism $(\beta=.125, \mathrm{p}<.01)$. While the conscientiousness personality traits of the teacher candidates predicted their less meaninglessness, neuroticism accompanies the feeling of meaninglessness at a higher level. The model created for the powerlessness dimension explained about $8 \%$ of the variance. For this dimension, the only personality trait that made a significant contribution to the model was conscientiousness $(\beta=-.-.170, p<.01)$. The conscientiousness personality traits of teacher candidates corresponded to a lower perception of powerlessness. In the model created for the normlessness dimension, approximately $11 \%$ of the variance could be explained by the variables added to the model. Except for openness $(\beta=.044, p>.05)$, all other personality traits contributed significantly to the model. Extraversion $(\beta=.127, \mathrm{p}<.01)$ and neuroticism $(\beta=.148, \mathrm{p}<.01)$ predict normlessness positively, whereas agreeableness $(\beta=-.127, \mathrm{p}<.01)$ and conscientiousness $(\beta=-$ $.186, \mathrm{p}<.001)$ predict negatively. In other words, high levels of agreeableness and conscientiousness predicted low level of normlessness, while high levels of extroversion and neuroticism accompany high levels of normlessness. Finally, the model created for the isolation 
dimension explained about $11 \%$ of the variance. Agreeableness and neuroticism among personality traits contributed significantly to the model. While agreeableness negatively predicts isolation, neuroticism predicts positively. In other words, the high agreeableness personality trait of teacher candidates corresponded to experiencing low isolation, while high neuroticism corresponds to experiencing a high level of isolation.

\section{Discussion and Conclusion}

The current study investigated whether the personality traits of teacher candidates predicted their self-efficacy perceptions and their alienation from school. First of all, research results showed that there were significant relationships among teacher candidates' personality traits and their self-efficacy perceptions and their alienation from school. The second result of the study was about the personality traits predicting teacher candidates' self-efficacy perceptions. The results of the research provided evidence that when the gender and department selection decision was controlled, extroversion, agreeableness, conscientiousness and openness positively predict teacher candidates' self-efficacy perceptions, whereas neuroticism significantly predicts negatively. In the model, where self-efficacy was predicted, after personality traits were included in the model, a 30\% change occurred in the identified variant. In addition, gender as a control variable contributed significantly to the model. Finally, the results provided evidence that personality traits significantly predict school alienation subdimensions when gender and department selection decision variables were controlled. The results indicated that while conscientiousness from personality traits was a negative predictor of meaninglessness, powerlessness, and normlessness sub-dimensions, neuroticism was a positive predictor of meaninglessness, normlessness, and isolation dimensions. Agreeableness was a negative predictor for the normlessness and isolation dimension, while extraversion was an interestingly positive predictor for the dimension of normlessness. Openness did not make a significant contribution to any of the models related to the prediction of alienation subdimensions. In predicting alienation sub-dimensions, there was a change between $7 \%$ and $11 \%$ in the variance explained by adding personality traits to the model. In addition, the gender variable made a significant positive contribution to the models predicted by meaninglessness and normlessness.

It was commonly assumed that self-efficacy perception contributes to cognitive processes and performance, especially in areas requiring academic achievement (Bandura, 1999; Reaves \& Cozzens, 2018; Özdemir, Sahin, \& Öztürk, 2020). In this context, teacher candidates' perceptions of self-efficacy would contribute to their ability to benefit from their learning processes at a high level, to pursue the teaching profession as a career (Wiens \& Ruday, 2014), and to cope with professional problems in the first years of the assignment. The result of current research provided that personality traits were a variable that could affect teacher candidates' self-efficacy perceptions. This result was also consistent with the results of studies dealing with self-efficacy perception and personality traits (Biermann, Karbach, Spinath, \& Brünken, 2015; Buttner, Pijl, Bijstra, \& Van den Bosch, 2016; Jamil, Downer, \& Robert, 2012; Şenler, 2011). Physiological and emotional experiences expressed by Bandura (1993) as a source of selfefficacy were guiding in explaining the relationship between self-efficacy and personality traits. In the current study, it was determined that high levels of agreeableness, conscientiousness, openness, and extraversion accompanied high self-efficacy. Individuals with these personality traits tend to experience positive emotions and be collaborative. In other words, since the selfefficacy perceptions of individuals with positive personality traits would be high, the feedback they received from their environment would further increase their self-efficacy, and selfefficacy might be considered as a self-fulfilling prophecy. High level of neuroticism 
accompanied low self-efficacy in the study. High levels of neuroticism were characterized by depression, anxiety, hostility, and insecurity (Costa \& McCrae, 1992), so these individuals were more likely to experience negative emotions. As a result, it could be stated that negative experiences might reduce the self-efficacy perception of the individual.

As a result of the research, it was found that personality traits, except for openness, were a significant predictor of alienation. It was remarkable that especially conscientiousness from personality traits predicted alienation negatively and neuroticism predicts alienation positively. This result also supported the relevant research results in the literature (Sexton, 1983; Tolor \& Leblanc, 1971). Individuals with conscientiousness personality traits were goal-oriented and made effective planning, and their emotional states changed less (Vorkapić, Čepić \& Šekulja, 2016; Zhao \& Seibert, 2006). It can be asserted that these individuals had higher problem solving skills and passion for the target in the face of difficulties. Neuroticism describes individuals who are extremely pessimistic, who cannot easily control their emotions, who are introverted and who experience bipolar mood states. In addition, these people have low selfconfidence and a high feeling of burnout (Costa \& McCrae, 2006; Tutar, 2016). Considering these characteristics that may lead to negative emotional experiences, it can be predicted that these individuals who are not successful in solving problems or making the right decisions tend to move away from their positions and experience alienation when faced with difficulties (Alömeroğlu, Güney, Sundu Yaşar, \& Akyürek, 2018). Interestingly, extroverted personality trait predicted the normlessness dimension of alienation positively. Extroverted individuals are people who like to be in large groups, care about social relationships, and seek excitement and encouragement (Zhao \& Seibert, 2006). It might be pointed out that group norms and group commitment were more important for these individuals. We could put forward that extroverted individuals who chose between external rules and group obedience were to prioritize group obedience behaviour, so they were to experience a sense of normlessness.

The Big Five Factor Theory points out that measuring personality traits were able to form a valuable knowledge base in staff orientation and decision-making (Somer, 2000). In addition, an important aspect of the debate on whether personality traits could be considered as a selection criterion for employment and admission to a program was the issue of whether personality had changed or not. In a series of longitudinal studies, there were research results showing that the personality traits of teacher candidates remain fairly stable (Corcoran \& O'Flaherty, 2016; Ripski, LoCasale-Crouch, \& Lauren, 2011). Nonetheless, Ripski et al. (2011) reported that extroverted personality traits might change over time, while Wiens and Ruday (2014) claimed that all personality types had the capacity to be equally excellent teachers, based on the studies in the literature. The two main features emphasized in personality definitions were individual differences and stability. The structure that affects human behaviour and could change was defined as the characteristic adaptation affected by the human-environment relationship (McCrae \& Costa, 2003). Characteristic adaptation includes traits that were influenced by the environment such as acquired skills, habits, and attitudes. Therefore, although some aspects of personality remain unchanged, individuals can gain various attitudes and skills with the effect of the environment. Nevertheless, there was not enough research on the level of professional competence of teacher candidates with different personality traits for teaching at the end of the program, on the level of their professional success and whether they left the profession later. Although the results of our study showed that personality trait was a good predictor for self-efficacy, it could be stated that the predictor of personality trait for alienation from school was relatively low. In this context, instead of evaluating personality traits as selection criteria, we recommended that candidates with risky tendencies were identified upon entry to the program and supported by monitoring, evaluation and intervention programs. 
Self-efficacy perceptions are an important factor affecting the teacher candidates' experience in the education process, their capacity to cope with difficulties and their decision to continue their profession. Furthermore, alienation from school can lead to dropout, low academic achievement, isolation, and problematic student behaviour. It is possible to assert that these two variables will significantly influence the outputs of teacher training programs. Since personality traits can predict both self-efficacy perceptions of teacher candidates and their alienation from school, they can be utilized to determine the tendencies of the individuals at the beginning of teacher training programs and to prepare support programs. Discovering one's own characteristics, in other words, having high self-awareness contributes to adaptation to environmental conditions (Vorkapić, Čepić \& Šekulja, 2016). In this context, supporting teacher candidates in discovering and understanding their own personalities can help them feel more competent at the beginning of their teaching career (Mahoney \& Quick, 2000; Smidt, 2015). This current research showed that male candidate teachers were likely to suffer from alienation from school. Çelik (2020) explained this situation with the cultural characteristics of Turkish society and stated that in Turkish society, male students were given a social role for finding a job, gaining profession and earning money, and this role may cause future anxiety in male students and lead to alienation. As a result, it can be suggested that male teacher candidates should be followed more closely in the teacher training process.

This research had some limitations. First of all, since this study was a cross-sectional study, it did not give information as to whether there was a difference in the other variables depending on the likelihood that the personality traits of teacher candidates changed during the learning process. In future studies on personality traits, their relationship with different variables might be examined longitudinally. Another limitation of the research was related to the measurements. All data obtained were based on teacher candidates' perceptions of themselves and selfreported. In different studies, research could be conducted using different data collection methods such as observation and interview. Finally, since this study focused on psychological factors, environmental factors were ignored when examining the relationship between personality trait and alienation from school and self-efficacy. In later studies, personality traits and the effect of different environmental conditions on attitudes and behaviours would be examined.

\section{Acknowledgements}

This research did not receive any specific grant from funding agencies in the public, commercial, or not-for-profit sectors.

\section{References}

Alömeroğlu, E., Güney, S., Sundu, M., Yaşar, O., \& Akyurek, S. (2017). The relationship between five factor personalities and alienation to work of nurses in teaching and research hospitals. Eurasia Journal of Mathematics, Science and Technology Education, 14(1), 117-122.

Bandura, A. (1993). Perceived self-efficacy in cognitive development and functioning. Educational psychologist, 28(2), 117-148.

Bandura, A. (1997). Self-Efficacy: The Exercise of Control. New York: W H Freeman/Times Books/ Henry Holt.

Bandura, A. (1999). Social cognitive theory of personality. Handbook of personality, 2, 15496. 
Benet-Martínez, V., \& John, O. P. (1998). Los Cinco Grandes across cultures and ethnic groups: Multitrait-multimethod analyses of the Big Five in Spanish and English. Journal of personality and social psychology, 75(3), 729-750.

Biermann, A., Karbach, J., Spinath, F. M., \& Brünken, R. (2015). Investigating effects of the quality of field experiences and personality on perceived teaching skills in German preservice teachers for secondary schools. Teaching and Teacher Education, 51, 77-87. http://dx.doi.org/10.1016/j.tate.2015.06.005

Burger, J. M. (2006). Kişilik [Personality] (Çev. İ. D. E. Sarığlu). İstanbul: Kaknüs Publishing.

Buttner, S., Pijl, S. J., Bijstra, J., \& Van den Bosch, E. (2016). Personality traits of expert teachers of students with EBD: Clarifying a teacher's X-factor. International Journal of Inclusive Education, 20(6), 569-587.

Canbulat, M., \& Kutluca-Canbulat, A. N. (2015). Avusturya ve Türkiye'de öğretmen adayı belirleme süreci [The Selection Process of Teacher Candidate in Austria and Turkey]. Pegem Education and Instruction Journal, 5(1), 113-132. doi: 10.14527/pegegog.2015.006

Costa Jr, P. T., \& McCrae, R. R. (1992). Four ways five factors are basic. Personality and individual differences, 13(6), 653-665

Costa, P. T., \& McCrae, R. R. (2006). Revised NOE Personality Inventory (NEO-PI-R) and NEO Five-Factor Inventory (NEO-FFI): Professional Manual. UK ed. Oxford: Hogrefe.

Corcoran, R. P., \& O'Flaherty, J. (2016). Personality development during teacher preparation. Frontiers in Psychology, 7, 1-10. doi: 10.3389/fpsyg.2016.01677

Corcoran, R. P., \& O'Flaherty, J. (2018). Factors that predict pre-service teachers' teaching performance. Journal of Education for Teaching, 44(2), 175-193.

Çağlar, Ç. (2012). Öğrenci Yabanc1laşma Ölçeği'nin (ÖYÖ) geliştirilmesi [Development of the Student Alienation Scale (SAS)]. Education and Science, 37(166), 195-205.

Çapa, Y., Çakıroğlu, J., \& Sarıkaya, H. (2005). The development and validation of a Turkish version of teachers' sense of efficacy scale. Education and Science, 30(137), 74-81.

Çelik, M. \& Şengül, M. (2017). Türkçe Öğretmeni Adaylarının Kişilik Özellikleri ve Mesleki Kayg1 Düzeyleri Arasındaki İlişkinin İncelenmesi [The Relation Between the Occupational Anxiety Level and Personal Characteristics of Turkish Teacher Candidates.] International Journal of Turkish Literature Culture Education, 6(4), 25972615.

Çelik, O. T. (2020). Prediction of alienation from university according to gender, department selection, academic success and academic self-efficacy. Inonu University Journal of the Faculty of Education (INUJFE), 21(2), 813-826.

Çokluk, Ö. (2010). Lojistik regresyon analizi: Kavram ve uygulama [Logistic Regression: Concept and Application]. Educational Sciences: Theory \& Practice, 10(3), 1357-1407.

DeMauro, A. A., \& Jennings, P. A. (2016). Pre-service teachers' efficacy beliefs and emotional states. Emotional and Behavioural Difficulties, 21(1), 119-132. https://doi.org/10.1080/13632752.2015.1120057

Dere, Z. (2018). Anaokulu öğretmen adaylarının kişilik özellikleri ile iletişim becerileri arasındaki ilişkinin incelenmesi [Investigation of the Relationship Between Personal Traits of Candidate Pre-School Teachers and Communication Skills]. Abant İzzet Baysal University Journal of Education Faculty, 18 (4), 1991-2010.

Erdoğan, İ. (2007). İşletmelerde Davranış [Behaviour in organizations]. İstanbul: Kişisel Publishing.

Evans, P., Martin, A. J., \& Ivcevic, Z. (2018). Personality, coping, and school well-being: an investigation of high school students. Social Psychology of Education, 21(5), 10611080. 
Fraenkel, J. R., Wallen, N. E., \& Hyun, H. H. (2012). How to design and evaluate research in education. New York, NY: McGraw-Hill.

Göncz, L. (2017). Teacher personality: a review of psychological research and guidelines for a more comprehensive theory in educational psychology. Open Review of Educational Research, 4(1), 75-95. https://doi.org/10.1080/23265507.2017.1339572

Güney, S. (2014). Davranış bilimleri [Behavioural sciences]. Ankara: Nobel Academy.

İnanç, B. Y., \& Yerlikaya, E. E. (2011). Kişilik Kuramları [Theories of Personality], Ankara. Pegem Academy Publishing.

Jamil, F. M., Downer, J. T., \& Pianta, R. C. (2012). Association of pre-service teachers' performance, personality, and beliefs with teacher self-efficacy at program completion. Teacher Education Quarterly, 39(4), 119-138.

Karagöz, Y. (2016). SPSS 23 ve AMOS 23 uygulamalı istatistiksel analizler [SPSS 23 and AMOS 23 Applied Statistical Analysis]. Nobel Academic Publishing.

Kızıltepe, Z. (2002). İyi ve etkili öğretmen [Good and Effective Teacher]. Education and Science, 27(126), 10-14.

Kim, L. E., Dar-Nimrod, I., \& MacCann, C. (2018). Teacher personality and teacher effectiveness in secondary school: Personality predicts teacher support and student selfefficacy but not academic achievement. Journal of Educational Psychology, 110(3), 309-323. https://doi.org/10.1037/edu0000217

McCrae, R. R., \& Costa, P. T. (2003). Personality in adulthood: A five-factor theory perspective. Guilford Press.

Mahoney, J. M., \& Quick, B. G. (2000). Personality correlates of alienation in a university sample. Psychological Reports, 87(3), 1094-1100.

Mann, S. J. (2001). Alternative perspectives on the student experience: Alienation and engagement. Studies in higher education, 26(1), 7-19.

Mete, Y. A. (2013). Güney Kore, Japonya, Yeni Zelanda ve Finlandiya' da öğretmen yetiştirme ve atama politikaları [Teacher education and appointment policies in New Zealand, South Korea, Japan and Finland]. Turkish Studies, 8(12), 859-878.

Noreen, S., Ali, A., \& Munawar, U. (2019). The Impact of Teachers' Personality on Students' Academic Achievement. Global Regional Review (GRR), IV (III), 1-15.

Osin, E. N. (2017). The category of alienation in educational psychology: Its history and prospects. Russian Education \& Society, 59(5-6), 256-273.

Özabacı, N., \& Acat, M. B. (2005). Öğretmen adaylarının kendi özellikleri ile ideal öğretmen özelliklerine dönük algılarının karşılaştırılması [A Comparative Study of Ideal and Self Characteristics of Teacher Candidates]. Educational Administration: Theory and Practice, 42(42), 211-236.

Özdemir, G., Sahin, S., \& Öztürk, N. (2020). Teachers' self -efficacy perceptions in terms of school principal's instructional leadership behaviours. International Journal of Progressive Education, 16(1), 25-40. https://doi.org/10.29329/ijpe.2020.228.3

Özer, B., \& Alkan, S. (2017). AB ve Türkiye öğretmen yetiştirme programlarının karşılaştırılması ve türkiye için bir model önerisi [Comparison of Teacher Training Programmes of EU and Turkey and A Model Suggestion for Turkey]. The Journal of Interdisciplinary Educational Research, 1(1), 62-95.

Özkan, M., \& Arslantaş, H. İ. (2013). Etkili öğretmen özellikleri üzerine sıralama yöntemiyle bir ölçekleme çalışması [A Study of Scaling with Ranking Judgment Method on Characteristic of Effective Teacher]. Trakya University Journal of Social Science, 15(1), 311-330. 
Perera, H. N., Granziera, H., \& McIlveen, P. (2018). Profiles of teacher personality and relations with teacher self-efficacy, work engagement, and job satisfaction. Personality and Individual Differences, 120, 171-178. https://doi.org/10.1016/j.paid.2017.08.034

Polat, M., \& Arabacı, İ. B. (2012). Türkiye'de eğitim fakültelerine öğrenci alım ölçütlerini yeniden düşünmek: karşılaştırmalı bir yaklaşım [Reconsideration of Student Enrolling Criteria to Schools of Education in Turkey: A comparative Approach]. Journal of Research in Education and Teaching, 1(3), 77-83.

Polat, M., Dilekmen, M., \& Yasul, A. F. (2015). Öğretmen adaylarında okula yabancılaşma ve akademik öz-yeterlik: Bir chaid analizi incelemesi [School Alienation and Academic Self-Efficacy in Prospective Teachers: A Investigation of Chaid Analysis]. The Journal of International Education Science, 4, 214-232.

Reaves, S.J. \& Cozzens, J.A. (2018). Teacher perceptions of climate, motivation, and selfefficacy: 1s there really a connection. Journal of Education and Training Studies, 6 (12), 48-67.

Rimm-Kaufman, S. E., \& Hamre, B. K. (2010). The role of psychological and developmental science in efforts to improve teacher quality. Teachers College Record, 112(12), 29883023.

Ripski, M. B., LoCasale-Crouch, J., \& Decker, L. (2011). Pre-service teachers: Dispositional traits, emotional states, and quality of teacher-student interactions. Teacher Education Quarterly, 38(2), 77-96.

Sexton, M. E. (1983). Alienation, dogmatism, and related personality characteristics. Journal of Clinical Psychology, 39(1), 80-86.

Smidt, W. (2015). Big Five personality traits as predictors of the academic success of university and college students in early childhood education. Journal of Education for Teaching, 41(4), 385-403. https://doi.org/10.1080/02607476.2015.1080419

Somer, O. (2000). The Relationship Between Personality Dimensions and Several Jobs According to Five Factor Model. Ege Journal of Education, 1 (1), . Retrieved from https://dergipark.org.tr/en/pub/egeefd/issue/4924/67359

Sümer, N., Lajunen, T., \& Özkan, T. (2005). Big five personality traits as the distal predictors of road accident. Traffic and transport psychology: Theory and application, 215, 215227.

Şenler, B. (2011). Pre-service science teachers'self-efficacy in relation to personality traits and academic self-regulation. (Doctoral dissertation). Retrieved from https://tez.yok.gov.tr/. (Accession number: 300744)

Tolor, A., \& Leblanc, R. F. (1971). Personality correlates of alienation. Journal of Consulting and Clinical Psychology, 37(3), 444. https://doi.org/10.1037/h0031952

Tschannen-Moran, M., and A. Woolfolk Hoy. 2001. "Teacher efficacy: capturing an elusive construct." Teaching and Teacher Education, 17, 783-805. doi:10.1016/S0742051X(01)00036-1

Tutar, H. (2016). Davranış bilimleri [Behavioral sciences], Seçkin Yayıncılık: Ankara.

Ubuz, B., \& Sarı, S. (2009). Sınıf öğretmeni adaylarının iyi öğretmen olma ile ilgili görüşleri [Primary Teachers Candidates' Views on Good Teacher]. Ondokuz Mayis University Journal of Education Faculty, (28), 53-61.

Üstüner, M. (2017). Personality and attitude towards teaching profession: Mediating role of self-efficacy. Journal of Education and Training Studies, 5(9), 70-82. https://doi.org/10.11114/jets.v5i9.2536

Vorkapić, S. T. (2015). How much personality is important in educational context? In: M. Orel (ed.), International Conference EDUvision 2015: "Modern Approaches to Teaching Coming Generation” (pp. 75-83). EDUvision, Stanislav Jurjevčič, Ljubljana, Slovenija. 
Retrieved from http://eduvision.si/Content/Docs/Zbornik\%20prispevkov\%20 EDUvision\%202015.pdf

Vorkapić, S. T., Čepić, R., \& Šekulja, I. (2016). Are there any differences in personality traits and life satisfaction between future preschool and primary school teachers?. Journal of Research in Childhood Education, 30(3), 361-373.

Wiens, P. D., \& Ruday, S. (2014). Personality and Preservice Teachers: Does It Change, Does It Matter?. Issues in Teacher Education, 22(2), 7-27.

Yaman, S., Koray, Ö., C., \& Altunçekiç, A. (2004). Fen bilgisi öğretmen adaylarının öz-yeterlik inanç düzeylerinin incelenmesi üzerine bir araştırma [A Research on the Investigation of the Self-Sufficiency Belief Levels of the Science Education Teacher Candidates]. The Journal of Turkish Educational Sciences, 2(3), 355-364.

Yeşilyurt, E. (2013). Teacher self-efficacy perceptions of teacher candidates. Electronic Journal of Social Sciences, 12(45), 88-104.

Zayim K., M. (2018). İlişkisel yöntem. K. Beycioğlu, N. Özer ve Y. Kondakçı (Ed.). Eğitim yönetiminde araştırma içinde [In Research in Educational Administration] (s. 269-287). Ankara: Pegem Academy.

Zhao, H., \& Seibert, S. E. (2006). The big five personality dimensions and entrepreneurial status: A meta-analytical review. Journal of applied psychology, 91(2), 259-271. 